\title{
層中間ピン柱脚機構を有する 鉄骨ラーメン骨組の終局耐震能力評価のための修正 D值法の提案 MODIFIED D-VALUE METHOD TO PREDICT SEISMIC STRENGTH OF MULTI-STORY STEEL
MOMENT RESISTING FRAMES WITH MID-STORY PIN COLUMN BASE SYSTEM
}

木村祥裕 ${ }^{* 1}$, 安藤素子 ${ }^{* 2}$, 古川 幸*3 Yoshihiro KIMURA, Motoko ANDO and Sachi FURUKAWA

\begin{abstract}
The D-value method a simple method to predict story drift distribution of a moment-resisting frame under lateral forces. This paper evaluates elasto-plastic behavior of a steel moment-resisting frame adopting a mid-story pin column base system, which has been introduced to prevent column bases from yielding. The proposed modified D-value method successfully predict moment and story drift distributions of the low-to-mid story frames with mid-story pin column base system. By the D-value method, it is shown that flexural demand on columns exceed twice as large as the full-plastic moment of beams for 6- and 9-story frame.
\end{abstract}

Keywords : Steel Moment Resisting Frame, Mid-story Pin Column Base System, Beam Yielding Mechanism, Modified D-Value Method 鉄骨ラーメン骨組，層中間ピン样胠機㗕，全層潹降伏型メカニズム，修正D值去

1. 序

\section{1 本研究の背景}

大地震に対する鉄骨ラーメン骨組の保有水平耐力計算等では，梁 の塑性化により全体崩壞形を形成させることで，建物の倒壊を防ぐ ことを目指すものであるが，その際，最下層柱脚の塑性化を許容し ている ${ }^{1)}$ 。しかし，1995 年の兵庫県南部地震では多くの鉄骨骨組が 倒壊しており, 2007 年の E-ディフェンスの実大振動台実験では, 現 行の保有水平耐力計算に基づき耐震設計された 4 層鉄骨ラーメン骨 組が，1995 年の兵庫県南部地震（JR 鷹取波）により, 最下層柱脚 の塑性化後, 柱頭でも塑性化を生じ, 最終的には局部座屈により最 下層で層崩壊した ${ }^{2)}$ 。一般的な耐震設計では $\mathrm{Ai}$ 分布に基づいた地震 外力を受けるラーメン骨組の応力分布や塑性ヒンジ分布を静的増分 解析により求め, 設計者の経験則に基づき終局メカニズムが定めら れる。しかし, 柱や梁等の部材の曲げ剛性と曲げモーメント分布（反 曲点位置）の関係を陽な形で表せないため, 骨組の部材断面の変化 に伴い，試行錯誤的に適切な部材を選定している。

水平力を受けるラーメン骨組の曲げモーメント分布を評価する簡 便な手法として D 值法が挙げられる ${ }^{3)}$ 。D 值法は最下層柱を固定も しくはピンとしたラーメン骨組の弾性時の曲げモーメント分布や層 剛性を求める簡易的な手法であるが，梁もしくは柱の塑性化後の曲 げモーメント分布や層剛性などを求めることはできない。

一方で，骨組の保有水平耐力時であっても柱が弾性保持される層 中間ピン柱脚機構が提案され，この柱脚機構を有する鉄骨ラーメン
骨組が全層梁降伏メカニズムを形成できることが示された ${ }^{4)}$ 。また， 層中間ピン柱脚を用いることで，柱梁耐力比 1.4 2.1 の 3,6,9 層の 3 スパン骨組において, 幅厚比が FA ランク, FB ランクいずれであっ ても柱の部材崩壊を防げることが明らかにされた ${ }^{5)}$ 。さらに，層中 間ピン柱脚を適用した一般的な骨組の中柱における応答性状を評価 するために，文献 6)を参考に，ラーメン骨組を魚骨形骨組に置換し た。その結果，従来の埋込み柱脚を適用したラーメン骨組を魚骨形 骨組に置換した場合に比べて，より精度良く保有性能を評価できる ことが示された ${ }^{7)}$ 。具体的には，柱梁曲げ剛比 $\left(\left(E I_{C} / h_{C}\right) /\left(E I_{B} / l_{B}\right)\right)$ を 変化させた場合の地震応答解析結果により, 柱頭作用曲げモーメン 卜が最大で梁の全塑性耐力の 2 倍程度となることが示されている7)。 以上の層中間ピン柱脚を適用した骨組の保有性能の評価に加えて, 提案した柱脚機構の実用化を可能とするために，ピン接合となる接 合部ディテールが開発され，鉄骨柱支点部の要求性能も明らかにさ れた ${ }^{8) 9}$ 。

\section{2 本論文の目的と構成}

本論文では，層中間ピン柱脚機構を有する鉄骨ラーメン骨組 4)5,77 -9) の弾塑性領域における力学特性の評価を行う手法として，文 献 3）の D 值法を基にした, 修正 $\mathrm{D}$ 值法を新たに提案する。従来型 骨組を想定した D 值法を層中間ピン柱脚骨組に適用するため，新た に柱脚形式による反曲点高さの修正を追加する。さらに, 弾塑性範 囲での評価を可能とするために，塑性化した梁を順次取り除き，骨 組の力学モデルを逐次更新する。それぞれの力学モデルに対して,
*1 東北大学大学院工学研究科 教授 ·博士 (工学)

*2 秋田県庁 修士 (工学)

*3 東北大学大学院工学研究科 助教 $\cdot$ 博士 (工学
Prof., Graduate School of Eng., Tohoku University, Dr.Eng.

Akita Prefectural Office, M.Eng.

Assist. Prof., Graduate School of Eng., Tohoku University, Dr.Eng. 
柱及び梁の曲げモーメントや骨組各層の水平変位を増分量として算 出寸る。これらを足し合わせていくことで, 弾塑性領域における骨 組の力学的特性を求める。修正 D 值法では, 骨組のモーメントや変 形量を決定する骨組諸元を, 層高さ分布, 柱梁剛比, 梁剛比分布, 柱脚形式という因子に分解寸ることができる。そのため, 因子ごと に骨組の力学的特性への影響を定量的に評価できるという特徵を有 する。したがって, 数值解析とは異なり, 修正 $\mathrm{D}$ 值法を用いること で, 骨組諸元と骨組の力学的特性の関係の定量的な評価が可能とな り, より合理的な骨組の部材選定ができる。本論文では, 提案する 修正 D 值法の妥当性を静的増分解析及び地震応答解析により検討し, 骨組が全層梁降伏メカニズムを形成するまでの各層の梁が塑性化す るときの層間変形角と柱作用曲げモーメントの関係を把握する。そ して, 各層の梁塑性ヒンジ形成時に柱が弾性保持するための柱曲げ 耐力を明らかにする。

本論文の構成は次のとおりである。2 章では, $\mathrm{D}$ 值法 ${ }^{3)}$ を基に層中 間ピン柱脚骨組に適用でき, かつ骨組の弾塑性挙動まで追従可能な 修正 D 值法を提案する。3 章では, 修正 D 值法で算定した層中間ピ ン柱脚を有する魚骨型鉄骨ラーメン骨組の各層の柱反曲点, 層せん 断力, 層間変位の精度を, 静的増分解析結果により検証する。4 章 では地震動を受ける層中間ピン柱脚骨組の動的応答性状を明らかに し, 地震応答解析結果のばらつきと修正 $\mathrm{D}$ 值法による算定值の対応 から修正 D 值法の適用範囲を検証する。5 章では, 本論文で得られ た知見をまとめる。

\section{2. 修正 $\mathrm{D}$ 值法における各層梁の塑性化時の層せん断カと層間変形 角の導出}

本章では，層中間ピン柱脚を有するラーメン骨組に D 值法 ${ }^{3) を}$ 用し，全層梁降伏が形成されるまでの曲げモーメント分布，層せん 断力及び層間変形角を算出するための定式化を行う。本論文ではこ の手法を修正 D 值法と称する。文献 7)では, 層中間ピン柱脚を用い た鉄骨ラーメン骨組の魚骨形モデルへの適用が行われ，良い精度で 骨組の応答を評価できることが示されている。したがって，ここで は $n$ 層の魚骨形骨組を対象とする。一般層を $i$ 層とし, 一般層の柱 を $i$ 層柱, その上下端に取りつく梁をそれぞれ $i$ 層と $i-1$ 層の梁と定 義する (図 1)。D 值法で定められる $i$ 層の柱梁曲げ剛比 $k_{i}$ は, (1) 式で定義される。ここで， $k_{C i}, k_{B i}$ は図 1 に定義する $i$ 層の柱及び梁 の曲げ剛性である。図中の $h_{C i}, l_{B i}$ は $i$ 層の層高さと梁のスパン長で あり， $I_{C i}, I_{B i}, E$ はそれぞれ柱と梁の断面 2 次モーメント, ヤング係 数である。
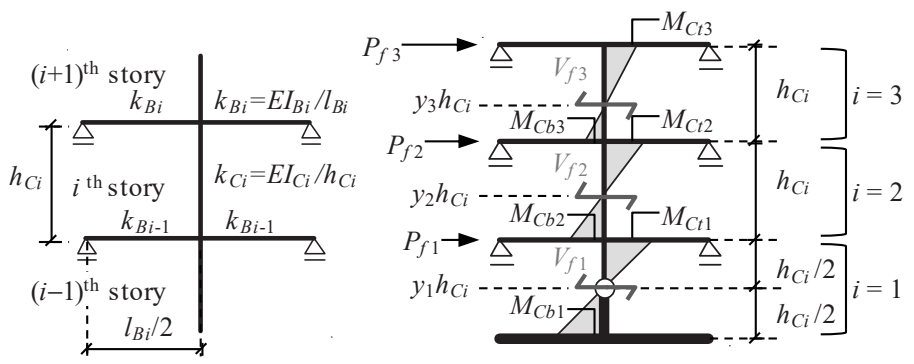

Fig. 1 Story unit model for D-value method

Fig.2 Definition of stress distribution of frame with mid-story pin column base $(n=3)$
$k_{i}=k_{C i} / 2 k_{B i}$

図 2 に, 3 層骨組 $(n=3)$ の場合における, 外力分布 $P_{f i}$ に対寸る 曲げモーメント分布を示す。 $i$ 層の反曲点高さ比 $y_{i}$ は層高さ $h_{C i}$ に対 する反曲点高さの比であり, $i$ 層柱脚曲げモーメント $M_{C b i}$ と層せん 断力 $V_{f i}$ を用いて，(2)式で表される。

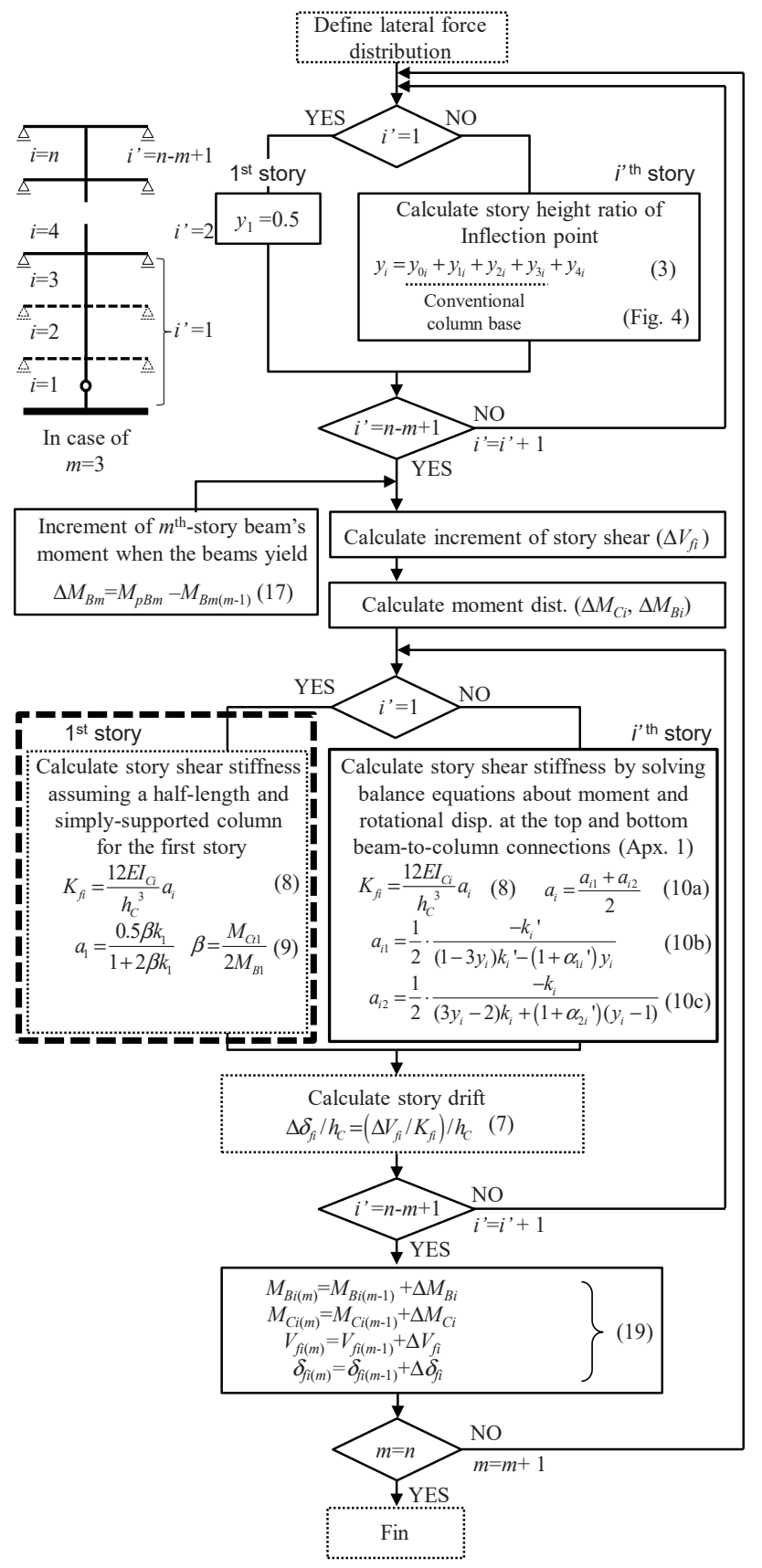

(a) Elastic frame $(m=1)$

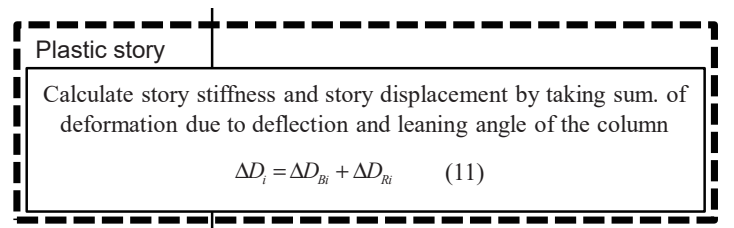

(b) Plastic frame $(1<m \leq n)$

Fig.3 Flow chart of modified D-value method 


$$
y_{i}=M_{C b i} /\left(V_{f i} h_{C i}\right)
$$

\section{1 弾性時における柱の反曲点高さ及び層間変形角の導出}

図 3(a)に, 修正 D 值法による弾性時の反曲点高さ, 曲げモーメ ント分布, 層せん断力, 層間変形角の算出方法のフローチャート を示す。文献 3)に基づく方法を点線, 本論文で新たに提案する方 法を実線で囲う。

\subsection{1 弾性時における柱の反曲点高さ}

\section{(i) 最下層}

層中間ピン柱脚骨組では, 最下層 $(i=1)$ の反曲点高さ比 $y_{1}$ を 0.5 と定める。

\section{(ii ) 一般層}

一般層の反曲点高さ比 $y_{i}$ は, フローチャート(図 3(a)）中の(3) 式で表される。ここで, $y_{0 i}$ は $i$ 層の標準反曲点高さ比であり, 柱脚 形式が柱脚固定, 柱梁曲げ剛比及び層高が全層で均一な基準骨組に

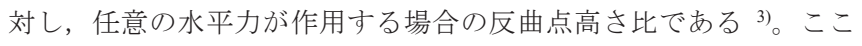
で，基準骨組の全層の柱梁曲げ剛比を $k$ ，層高さを $h_{C}$ とする。

$y_{1 i}$ は，基準骨組において任意の層（ $j$ 層とする）より上層で梁の 曲げ剛性が小さくなり, 柱梁曲げ剛比 $k$ が $j$ 層を境に ${ }_{1} \alpha_{j} k$ に切り替 わるときの反曲点高さ比の修正值である（図 4(a)）。修正 D 值法で は $y_{1 i}$ を算出する際に, 均一せん断力 $V_{f}$ を受ける骨組を想定し, 図 4(a)の破線で示す曲げモーメント分布のように反曲点高さ比を全層 0.5 とする ${ }^{3)}$ 。図 4(a)より, $j$ 層の反曲点高さ比の修正值 $y_{1 j}$ は, (2) 式を参考に, 柱梁曲げ剛比の変化による曲げモーメントの変動値 ${ }_{y 1 j} M_{C}$ により(4)式で表される。(4)式は, 文献 3)の(4.46)式に基づき, 算出したものである。算出方法は付録 1 に示す。 $j$ 層より下もしく は上の層である $i$ 層の曲げモーメントの変動值 ${ }_{y 1} M_{C i}$ は, ${ }_{11} M_{C j}$ に基 準骨組の柱梁曲代剛性比 $k$ による波及率 $r$, もしくは柱梁曲げ剛性 比 ${ }_{1} \alpha_{j} k$ による $r$ をを乗じることで算出される ((5)式, 図 4(a) )。 $i$ 層の 反曲点高さ比 $y_{1 i}$ の修正值は, ${ }_{y 1 j} M_{C i}$ と均一せん断力 $V_{f}$ により(2)式で 求められる。ここで, 波及率は, (5)式右で表され, 任意の層の柱梁 曲げ剛比の変化による, 近接する層の曲げモーメントの変動率であ る。曲げモーメントの変動值は, 柱梁曲げ剛比が変化する層から 2 層離れた層では $r^{2}, r^{2}$ と, 層をまたぐ毎に波及率の乗数で他層へと 伝達される（(5)式）。したがって, 反曲点高さ比の変化量は, 波及 元の層から 3 層以上またぐ層では影響は無視できる程度まで小さく なる。

$$
\begin{aligned}
& y_{1 j}=\frac{{ }_{y l j} M_{G G}}{V_{c} h_{C}}=\frac{1-{ }_{1} \alpha_{j}}{{ }_{1} \alpha_{j}(1-r+6 k)-\left(r^{\prime}-1\right)} \quad \text { (4)（文献 3) (4.46)式) } \\
& { }_{y 1 j} M_{Q}=\left\{\begin{array}{ccc}
{ }_{y 1 j} M_{G} r^{i-j} & (j \leq i) & \because r^{\prime}=\left(1+3_{1} \alpha_{j} k\right)-\sqrt{\left(1+3_{1} \alpha_{j} k\right)^{2}-1} \\
{ }_{y 1 j} M_{G} r^{j-i} & (i \leq j) & \because r=(1+3 k)-\sqrt{(1+3 k)^{2}-1}
\end{array}\right.
\end{aligned}
$$

（文献 3）(4.44)，(4.45)式）

$y_{3 i}$ は，基準骨組において任意の層（j 層とする）の層高のみが ${ }_{2} \alpha_{j}$ $h_{C}$ 一と変化するときの上層の反曲点高さ比の修正值である(図 4(b))。 修正 D 值法では $y_{3 i}$ を算出する際に, 均一せん断力 $V_{f}$ を受ける骨組 を想定し, 反曲点高さ比を全層 0.5 とする ${ }^{3)}$ 。このとき, 柱頭曲げ モーメントは $0.5 V_{f} h_{C}$ となるが, $j$ 層の層高が ${ }_{2} \alpha_{j} h_{C}$ に変化する場合,

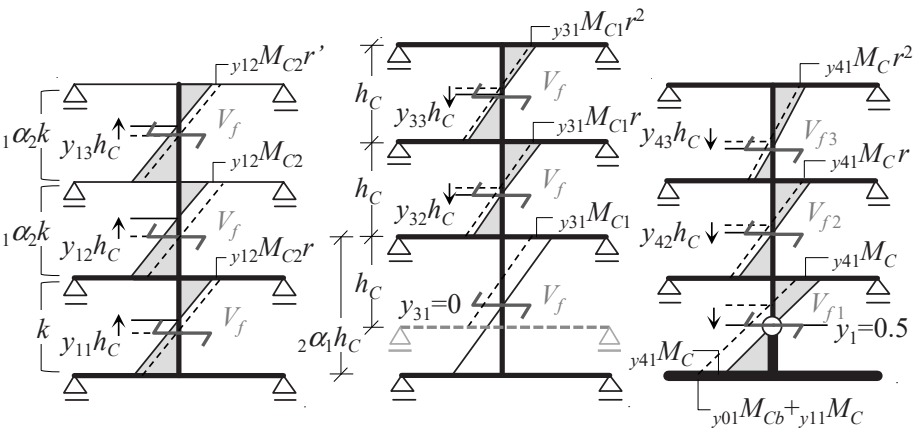

(a) For calculating $y_{1}$ (in case of $j=2$ )

$\begin{array}{ll}\text { (b) For calculating } y_{3} & \text { (c) For calculating } y_{4}\end{array}$ (in case of $j=1$ )

Fig.4 Simplified model of shear and moment distribution of frame for calculating story height ratio of inflection points $(n=3)$

$j$ 層柱頭曲げモーメントは $0.5_{2} \alpha_{j} V_{f} h_{C}$ となる。これらの曲げモーメン トの差を不釣り合い曲げモーメント ${ }_{y 3 j} M_{C j}$ とする。 $j+1$ 層柱脚の曲げ モーメントの変動值 $y_{3}{ }_{j} M_{C(j+1)}$ は, この不釣り合い曲げモーメント ${ }_{y 3 j} M_{C j}$ に, 基準骨組の波及率 $r((5)$ 式) を乗じることで求められる（図 4(b))。反曲点高さ比の修正值 $y_{3 i}$ は, $y_{1 i}$ と同様に(2)式で求められる。 なお，図 3(a)中(3)式の $y_{2 i}$ は， $j$ 層の層高が変化するときの下層の反 曲点高さ比の修正值である。本論文では, 全層で層高さが均一な骨 組を検討対象とし，梁塑性化後における骨組の反曲点高さ比を算出 する際に $y_{3 i}$ の夕を用いることから (2.2 節)， $y_{2 i}$ については説明を割 愛する。

$y_{4 i}$ は，本論で新たに提案する反曲点高さ比の修正值で，最下層に 層中間ピン柱脚を採用する場合における，上層の反曲点高さ比の修 正值である（図 4(c)）。ここで想定する骨組は，任意の外力を受け， 反曲点高さ比は $y_{0 i}$ と $y_{1 i}$ を足し合わせたものとする。このとき，最 下層の反曲点高さ比は層中間のピン支承部高さ（図中○）とは一致 しない。そこで， $y_{01}, y_{11}$ より算出した最下層柱脚作用曲げモーメン 卜 ${ }_{y 01} M_{C b}, y 11 M_{C}$ の合計值に対して, 最下層での反曲点高さが層中間 のピン支承部高さに一致するように, 修正曲げモーメント ${ }_{y 41} M_{C}((6)$ 式）を最下層柱脚部に作用させる（図 4(c)）。上層の曲げモーメント の変動值は, ${ }_{441} M_{C}$ に基準骨組の波及率 $r$ を乗じることで算出される (図 4(c))。ここで，(6)式において，弾性時では $H_{m}=h_{C} / 2$ とする。 $H_{m}$ については, 2.2.2 項で説明する。

$$
{ }_{y 41} M_{C}=-\left({ }_{y 01} M_{C b}+{ }_{y 11} M_{C b}\right)\left\{\left(1-\frac{h_{C} / 2}{h_{C} / 2+H_{m}}\right) /\left(y_{01}+y_{11}\right)\right\}
$$

\subsection{2 弾性時における骨組の層間変形角}

$i$ 層の層間変形角 $\delta_{f i} / h_{C}$ は, 層せん断力 $V_{f i}$ と骨組の層剛性 $K_{f i}$ より 求められる（図 3(a)中 (7)式)。D 值法 ${ }^{3)}$ では, 両端固定の場合の曲 げ剛性に梁の曲げ剛性による端部の固定度を考慮した係数 $a_{i}$ を乗ず ることで層剛性 $K_{f i}$ を算出していることから (図 3(a)中 (8)式), 本項 でも同様に層中間ピン柱脚骨組の $K_{f i}$ の算出過程を示す。

\section{( i ) 最下層}

最下層柱の柱脚部の固定度を表す係数 $a_{1}$ は, $\mathrm{D}$ 值法 ${ }^{3)}$ ではピン柱 脚の場合，フローチャート（図 3(a)）中の(9)式として表される。層 中間ピン柱脚骨組の場合, ピン支承部から最下層梁高さまでを柱長 さ $\left(=h_{C} / 2\right)$ とし，(9)式を適用する。

(ii ) 一般層

一般層の層剛性 $K_{f i}$ については D 值法 ${ }^{3)}$ で反曲点を 0.5 に固定した 簡略的な算出方法が例示されている。一方, 文献 10)では柱上下端 

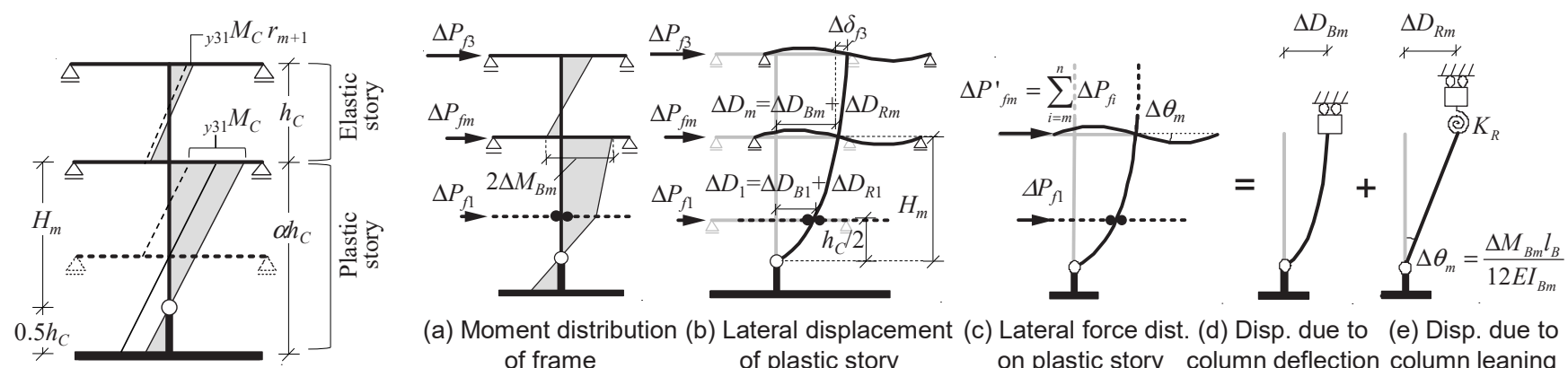

(a) Moment distribution (b) Lateral displacement (c) Lateral force dist. (d) Disp. due to (e) Disp. due to of frame of plastic story

on plastic story column deflection column leaning

Fig.5 Plastic frame model for calculating $y_{3}(n=3, m=2)$

Fig.6 Mechanical model for calculating displacement and moment distribution of plastic story $(m=2)$

に取りつく梁による回転拘束効果をたわみ角法により高い精度で求 めていることから，本論文でもこれを採用する。 $i$ 層柱の上下層梁 による回転拘束度を表す係数 $a_{i}$ は, フローチャート(図 3(a)) の(10a) 式に示すように, 係数 $a_{i 1}$ と $a_{i 2}$ の平均とする ${ }^{10)}$ 。ここで, 係数 $a_{i 1}$ は $i$ 層柱脚部節点回りの曲げモーメントの釣合方程式より ((10b)式), 係数 $a_{i 2}$ は $i$ 層柱頭部節点回りの曲げモーメントの釣合方程式より求 められる（(10c)式） ${ }^{10)}$ 。係数 $a_{i 1}$ と $a_{i 2}$ の算出方法は付録 2 に示す。

\section{2 梁塑性化層における反曲点高さ及び層間変形角の導出}

一般的な中低層の建物が現行の設計規準に従って設計される場合, 地震外力に対して設計されることに加えて, 1 次設計の変形制限に より，上層の梁断面が下層に対して極端に小さくならない。文献 4) 〜6)では, 既往の設計規準に基づいて設計された柱梁耐力比 1.2 2.1 の範囲の 3, 6, 9 層ラーメン骨組を対象に, $\mathrm{Ai}$ 分布による水平外力 を受ける場合の静的増分解析が行われた。その結果, 骨組に層中間 ピン柱脚を適用した場合は, 埋込み柱脚を適用した場合とは異なり, 梁が下層から上層に向かって順に塑性化し, 下層の梁ほど塑性変形 倍率も大きくなるという知見が示されている。本論文で提案する修 正 D值法では水平外力によって生じる曲げモーメントを受ける梁が, 下層から上層に向かって順次塑性化する場合を想定する。ここで, 梁の降伏が下層から上層の順とならない場合は，以下で定式化する 修正 D 值法の適用範囲外とする。

修正 D 值法では, 各層梁塑性化時の柱及び梁の曲げモーメント, 層間変形角は, 各層の梁塑性化までの層せん断力の増分に対して算 出し, 順次足し合わせて求める。ここで, 梁は完全弾塑性とし, 梁 塑性化後の梁端塑性ヒンジ位置の曲げ剛性を 0 とし, 増分計算時に は塑性化した梁を取り除く。つまり, 最下層の層中間ピン支承部か ら梁が弾性である $m$ 層を柱頭とする層 (以降, 塑性化層と呼ぶ) と, 上下の梁が塑性化していない一般層 (弾性層) で骨組が構成される (図 5)。ここで，塑性化層の層高さを $H_{m}$ と定義する。

図 3(b)に, 梁塑性化後の塑性化層の水平変位及び層剛性の算出方 法を示す。これは, 図 3(a)に示した弾性時における修正 D 值法のフ ローチャート中の太破線部分と対応し, それ以外の手順は図 3(a) と 同様である。ただし，塑性化層では，弾性時の計算フローとは異な り, 反曲点高さ比を算出せずに, 図 6 に示寸力学モデルについて柱 の曲げモーメント分布と各層の水平変位 $D_{i}$ を算出する。したがって, 図 3(a) の(7)式は, $\Delta \delta_{f i} / h_{C}=\left(\Delta D_{i}-\Delta D_{i-1}\right) / h_{C}$ となる。

\section{2.1 梁塑性化後における柱の反曲点高さ}

\section{（i）塑性化層}

最下層反曲点高さ比 $y_{1}$ は, 層中間ピン柱脚のピン位置とする。

\section{(ii ）一般層}

1 層から $m-1$ 層までの梁が塑性化した状態から新たに $m$ 層梁が塑 性化するとき， $m$ 層以下を最下層 $i^{\prime}=1$ (図 3 中左上に定義）とみな して弾性時 (2.1.1 節 ( ii ) ) と同様に, 弾性の柱とそれに取り付く上 下の梁で構成される一般層の反曲点高さ比 $y_{i}$, を算出する。その際, 最下層の層高が変化することから, 層高変化による修正項 $y_{31}$ を考慮 する。ここで, 修正 D 值法では最下層に層中間ピン柱脚を有するこ とを考慮し, 反曲点高さ比を図 $4(\mathrm{~b})$ のように 0.5 とするのではなく, 層中間ピン柱脚の位置に一致する曲げモーメント分布を想定する

(図 5)。上層への波及率は, 弾性層の最下層 $(m+1$ 層 $)$ の $r_{m+1}$ を用い る。

\section{2. 2 梁塑性化後における骨組の層間変形角}

\section{（i）塑性化層}

水平外力 $\Delta P_{f i}$ を受ける骨組において, 塑性化層の柱の変形状態を 図 6(b)のようにモデル化する。このとき, $i$ 層の水平変位 $\Delta D_{i}(i \leqq m)$ は，図 $6(\mathrm{c}) \sim(\mathrm{e})$ に示すように塑性化層の柱の曲げによる水平変位 $\Delta D_{B i}$ と柱頭の回転による水平変位 $\Delta D_{R i}$ の和と表される(フローチャ 一ト (図 3(b)）中 (11)式)。塑性化層の柱の曲げによる $i$ 層の水平変 位 $\Delta D_{B i}$ は, $j$ 層に作用寸る水平外力 $\Delta P_{f j}$ に対する $i$ 層柱頭の曲代水平 変位 $\Delta D_{B i, j}$ の和として(12) (14)式のように算出される (図 6(d))。こ こで, 塑性化層柱頭に作用寸る水平力 $\Delta P^{\prime}{ }_{f m}$ は, $m \sim n$ 層までの上層 の水平力の和として(15)式と定められる（図 6(c)）。また，(13), (14) 式中の $H_{i}$ は, 最下層の層中間ピン支承部からの $i$ 層までの高さとす る。

$$
\begin{aligned}
& \Delta D_{B i}=\sum_{j=1}^{m} \Delta D_{B i, j} \\
& \Delta D_{B i, j}=\frac{\Delta P_{f j} H_{i}}{E I_{C m}}\left(-\frac{H_{j}^{2}}{2}+H_{j} H_{m}-\frac{H_{i}^{2}}{6}\right) \quad(j \leq i) \\
& \Delta D_{B i, j}=\frac{\Delta P_{f j} H_{j}}{E I_{C m}}\left(-\frac{H_{i}^{2}}{2}+H_{i} H_{m}-\frac{H_{j}^{2}}{6}\right) \quad(j \geq i) \\
& \Delta P_{f m}^{\prime}=\sum_{i=m}^{n} \Delta P_{f i}
\end{aligned}
$$

一方, $\Delta D_{R i, m}$ は塑性化層の柱の上端に取り付く梁の端部回転角 $\Delta \theta_{m}$ により生じる $i$ 層柱頭の水平変位であり, (16)式で求められる。ここ で, $\Delta M_{B m}$ は $m-1$ 層梁塑性化時から $m$ 層梁塑性化時までの $m$ 層梁の 曲げモーメントの増分で, フローチャート（図 3(a)）中の(17)式よ り求められる。 $K_{R}$ は $m$ 層梁の端部回転角に対応寸る回転剛性で, (18) 式より求められる（図 6(e)）。 


$$
\Delta D_{R i, m}=\frac{2 \Delta M_{B m} H_{i}}{K_{R}} \quad(16), \quad K_{R}=\frac{12 E I_{B m}}{l_{B}}
$$

\section{(ii ) 一般層}

一般層の水平変位については2.1.2 項と同様の方法で算出する。

\section{2.3 骨組の曲げモーメント, 層せん断カ及び層間変形角の算出}

2.2.1 項及び 2.2.2 項より算出された $m-1$ 層梁塑性化時から $m$ 層梁 塑性化時までの曲げモーメント, 層せん断力及び層間変位の増分を それぞれ $m-1$ 層梁塑性化時の值に足し合わせることによって算出す る（(19)式)。

3. 層中間ピン柱脚骨組の弾塑性静的増分解析と修正 $D$ 值法との比 較

本章では, 修正 D 值法で算出した層中間ピン柱脚を有する骨組の 柱の曲げモーメント分布, 層せん断力及び層間変形角について, 弾 塑性静的増分解析結果と比較し, その妥当性を検証する。

\section{1 数值解析概要}

図 7 に層中間ピン柱脚を有する 6 層魚骨形骨組の数值解析モデル

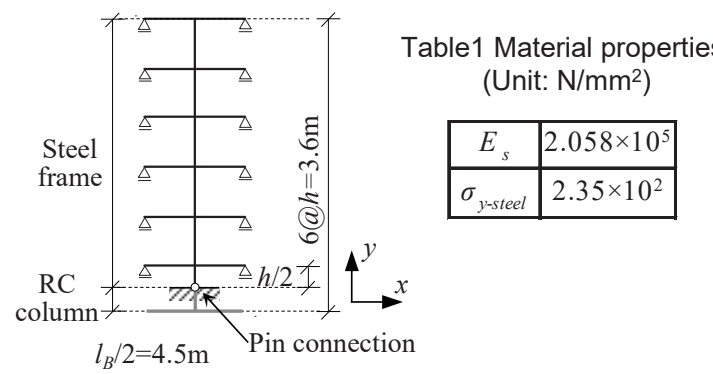

Fig.7 Simulation model

Table2 Section of components (Unit: $\mathrm{mm}, \mathrm{kNm}$ )

\begin{tabular}{|c|c|c|c|c|c|}
\hline & story & column & beam & $M_{p B i}$ & $\alpha_{i}$ \\
\hline \multirow{3}{*}{ 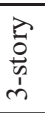 } & 3 & $\square-480 \times 18$ & H- $640 \times 200 \times 12 \times 16$ & 731 & \multirow{3}{*}{0.75} \\
\hline & $1-2$ & $\square-520 \times 19$ & H- $640 \times 250 \times 12 \times 19$ & 950 & \\
\hline & & $800 \times 800$ & $1200 \times 800$ & 7 & \\
\hline \multirow{3}{*}{$\begin{array}{l}\overrightarrow{0} \\
0 \\
0 \\
b\end{array}$} & $4-6$ & $\square-600 \times 20$ & H- $760 \times 270 \times 12 \times 19$ & 1262 & \multirow{3}{*}{0.75} \\
\hline & $1-3$ & $\square-630 \times 23$ & $\mathrm{H}-760 \times 310 \times 16 \times 22$ & 1666 & \\
\hline & & $800 \times 800$ & $1200 \times 800$ & 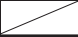 & \\
\hline \multirow{4}{*}{$\begin{array}{l}3 \\
0 \\
\text { क. } \\
a\end{array}$} & $7-9$ & $\square-590 \times 21$ & $\mathrm{H}-700 \times 300 \times 16 \times 22$ & 1457 & \multirow{4}{*}{0.85} \\
\hline & $4-6$ & $\square-610 \times 22$ & H- $800 \times 270 \times 16 \times 20$ & 1534 & \\
\hline & $1-3$ & $\square-610 \times 26$ & $\mathrm{H}-800 \times 300 \times 16 \times 22$ & 1745 & \\
\hline & & $1000 \times 1000$ & $1200 \times 1000$ & 7 & \\
\hline
\end{tabular}

を示す。数值解析プログラムは ABAQUS 6.14 を用いた。検討対象 モデルは，現行の設計規準に従って設計された梁先行降伏型の骨組 4) とする。柱及び梁は梁要素を用いる。柱と梁は剛接合, 左右の梁 の端部はピンローラー支持としている。 $\mathrm{RC}$ 柱と基礎梁は十分に剛

\begin{tabular}{|c|c|c|c|c|c|c|}
\hline & $\begin{array}{c}\text { 3- } \\
\text { story }\end{array}$ & $\begin{array}{l}6- \\
\text { story }\end{array}$ & $\begin{array}{c}\text { 9- } \\
\text { story }\end{array}$ & $\begin{array}{c}\text { Modified } \\
\text { D-value }\end{array}$ & $\begin{array}{l}\text { Simu- } \\
\text { lation }\end{array}$ & Error \\
\hline $\begin{array}{l}\text { distribution } \\
\text { at } M_{p B i} \quad i=\end{array}$ & & $\begin{array}{r}1^{\text {st }} \\
2^{\text {nd }}\end{array}$ & $3^{\text {st }}$ & $\stackrel{\bullet}{\circ}$ & $\Delta$ & $\square$ \\
\hline & $-3^{\text {rd }}$ & $4^{\text {th }}$ & $6^{\text {th }}$ & - & $\bar{\Delta}$ & \\
\hline
\end{tabular}

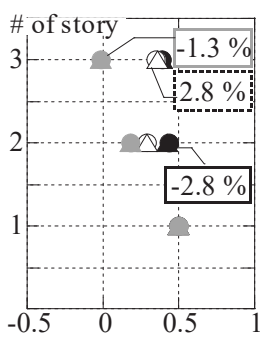

(a) 3-story frame

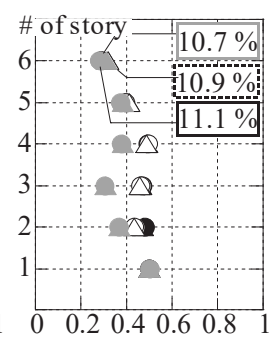

(b) 6-story frame

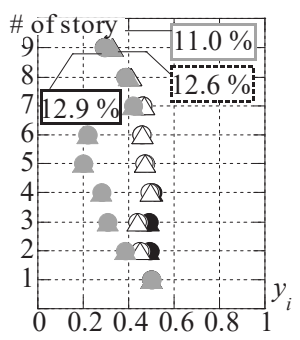

(c) 9-story frame

Fig. 8 Story height ratio of inflection point at $M_{P B i}$

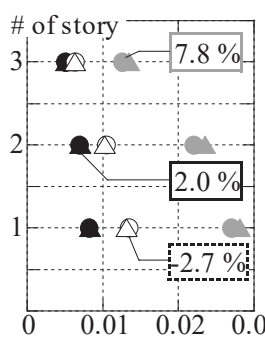

(a) 3-story frame

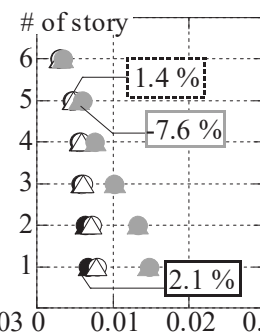

(b) 6-story frame Fig.9 Story drift at $M_{p}$

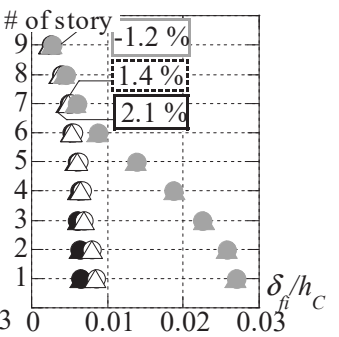

(c) 9-story frame

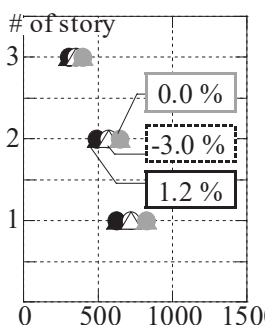

(a) 3-story frame

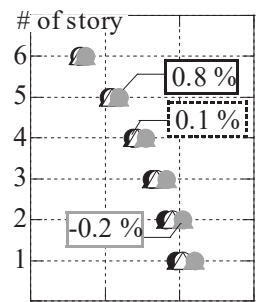

(b) 6-story frame Fig.10 Story shear at $M_{P B}$

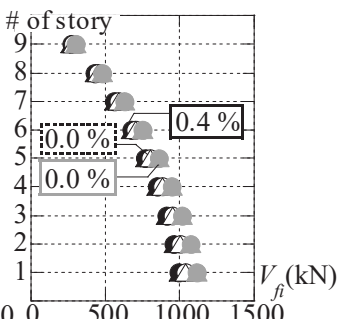

(c) 9-story frame

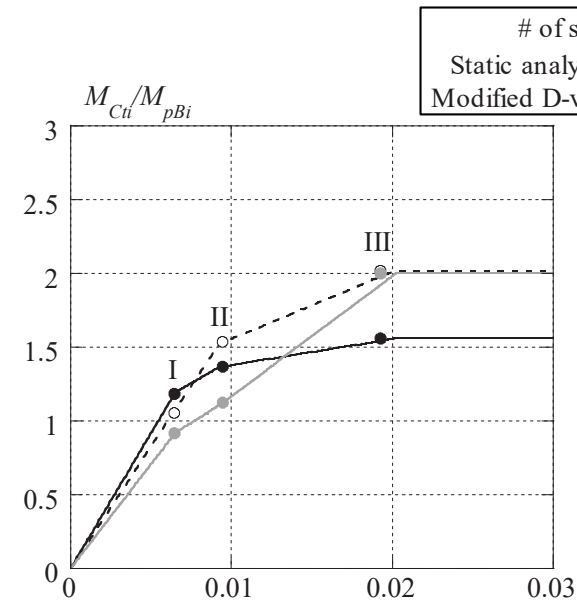

(a) 3-story frame of story: $1^{\text {st }} \quad 2^{\text {nd }} \quad 3^{\text {r }}$ $4^{\text {th }} \quad 5^{\text {th }} \quad 6^{\text {th }} \quad 7^{\text {th }} \quad 8^{\text {th }} 9^{\text {th }}$

$\bullet \quad 0 \quad \bullet \quad \Delta \quad \Delta \quad \Delta \quad \bullet \quad \diamond$

(b) 6-story frame

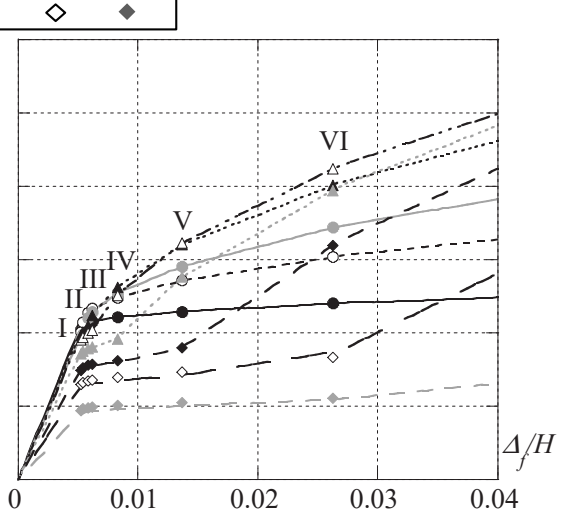

(c) 9-story frame

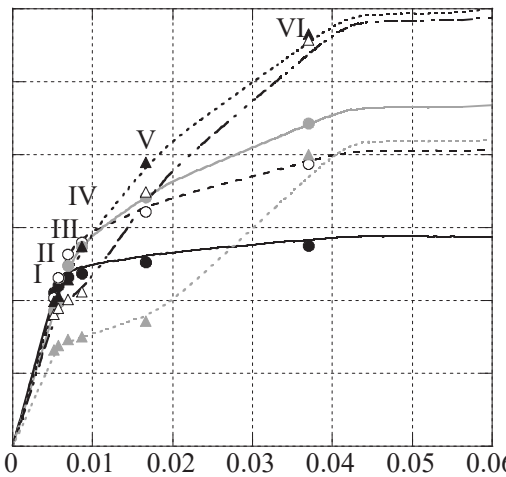

Fig.11 Relation between normalized flexural demand on column and roof displacement 
とし，鉄骨柱最下端をピン支持とすることで，最下層ピン支承部を モデル化する。

水平外力は $\mathrm{Ai}$ 分布に基づき設定する。鋼材及びコンクリートの材 料特性を表 1 に示す。鋼材の応力-歪関係は完全弾塑性とする。梁と 柱部材断面の組み合わせは塑性断面係数比で 1.8 に相当するが 7), 本論文では柱の最大作用曲げモーメントを明らかにするために柱を 弾性とする。表 2 に柱及び梁断面，各層梁全塑性モーメ

ント $\left(M_{p B i}\right)$ の值を示す。 $j$ 層における柱梁曲げ岡性比の変化の比率 ${ }_{1} \alpha_{j}$ は，D 值法における適用範囲が 0.7 程度とされていること ${ }^{3)}$, ま た, 既往の文献 4)で用いた骨組の柱梁曲げ剛性比を参考にして, 本 論文では 3 層， 6 層骨組では $0.75 ， 9$ 層骨組では 0.85 と寸る。

\section{2 数值解析結果}

図 8 に 3 層, 6 層及び 9 層骨組での各層 $M_{p B i}$ 時における反曲点高 さ比の修正 D 值法と数值解析結果の比較を示す。縦軸は層数, 横軸 は反曲点高さ比である。 3 層骨組では 1 層, 2 層及び 3 層 $M_{p B i}$ 時, 6 層骨組では 1 層, 2 層及び 4 層 $M_{p B i}$ 時, 9 層骨組では 1 層, 3 層及び 6 層 $M_{p B i}$ 時の結果をプロットしている。各層 $M_{p B i}$ 時の修正 $\mathrm{D}$ 值法に 対する数值解析の最大誤差率を求め, 誤差が最大となる層を示して いる。なお，凡例は図 9 及び図 10 でも同様とする。6 層及び 9 層骨 組では最上層で誤差が大きくなるが, 各層 $M_{p B i}$ 時における両者の結 果は全ての骨組において概ね一致している。

図 9 に 3 層, 6 層及び 9 層骨組での各層 $M_{p B i}$ 時における層間変形 角分布の修正 D 值法と数值解析の比較を示す。横軸は層間変形角で ある。反曲点高さ比と同様に, 上層の梁が塑性化するとき, 弾性時 よりも誤差が大きくなるが，両者の分布形状は概䄈一致している。

図 10 に 3 層, 6 層及び 9 層骨組での各層 $M_{p B i}$ 時における層せん断 力分布の修正 $\mathrm{D}$ 值法と数值解析の比較を示す。横軸は層せん断力で ある。各層 $M_{p B i}$ 時において両者はよく対応し, 上層の $M_{p B i}$ 時には修 正 D 值法と数值解析の差はほぼ 0 となっている。

図 11 に 3 層, 6 層及び 9 層骨組の柱頭作用曲げモーメントと頂部

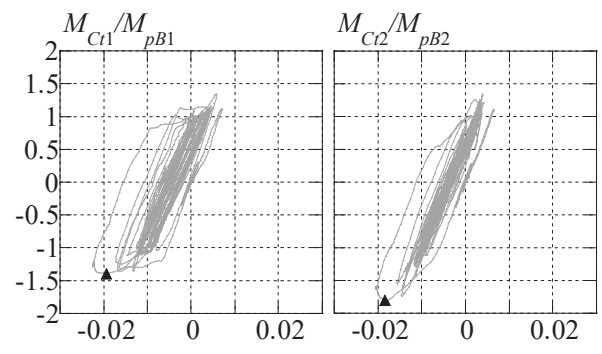

(a) Taft $75 \mathrm{~cm} / \mathrm{s}$
変形角の関係を示す。横軸は頂部変形角, 縦軸は必要柱梁耐力比を 示し, 各層柱頭曲げモーメントを各層 $M_{p B i}$ で除すことで無次元化し ている。数值解析結果を線で, 修正 D 值法による結果をプロットで 表し, 各層 $M_{p B i}$ 時を I 〜 VIで示す。また, 図 12 に修正 $\mathrm{D}$ 值法より 求めた, 3 層, 6 層及び 9 層骨組での各層 $M_{p B i}$ 時における柱作用曲 げモーメント分布を示す。縦軸は層数, 横軸は柱作用曲げモーメン トの值である。図 11 中の I のとき, 柱頭作用曲げモーメントの各層 $M_{p B i}$ に対する比は 1.0 程度であるが，梁が塑性化すると柱頭作用曲

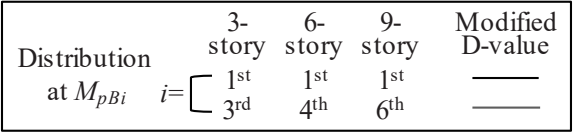

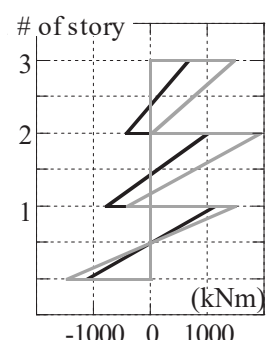

(a) 3-story frame

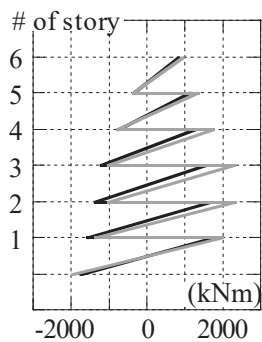

(b) 6-story frame Fig. 12 Column moment distribution at $M_{p B i}$

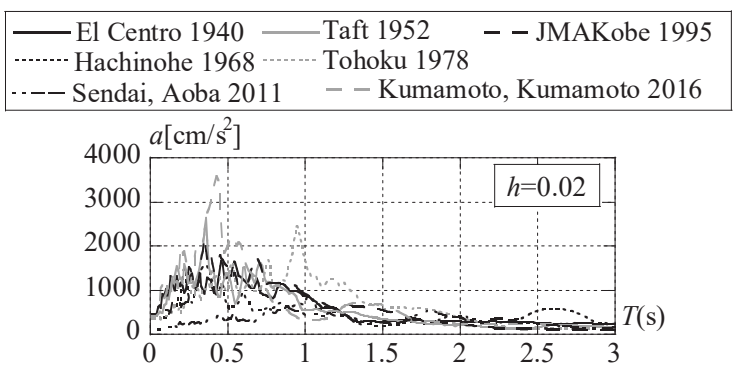

Fig.13 Pseudo acceleration spectra $(50 \mathrm{~cm} / \mathrm{s})$
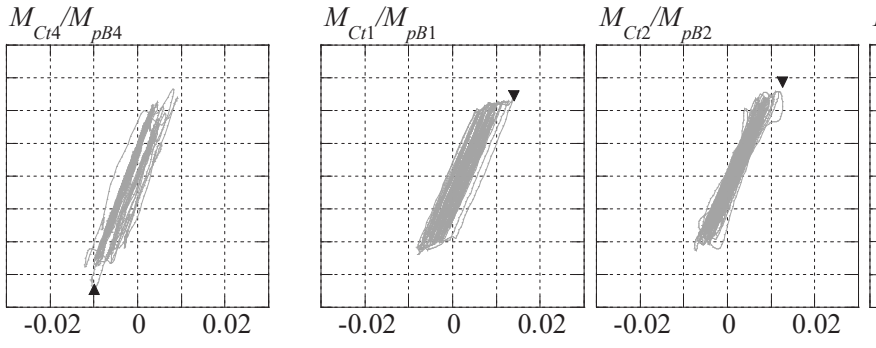

(b) Sendai, Aoba $75 \mathrm{~cm} / \mathrm{s}$

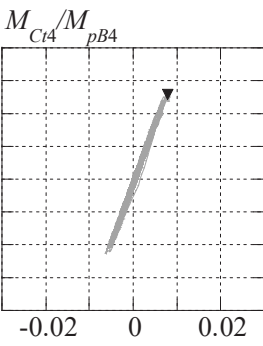

$\delta_{f i} / h_{C}$

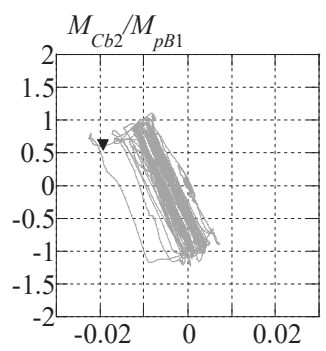

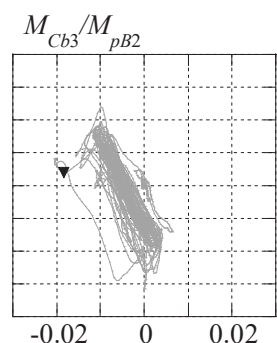

(a) Taft $75 \mathrm{~cm} / \mathrm{s}$

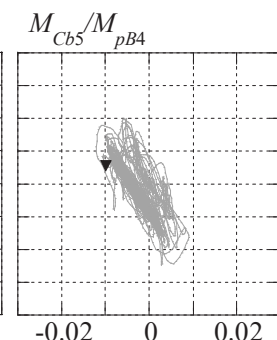

$\begin{array}{lll}-0.02 & 0 & 0.02\end{array}$

Fig.15 Relation between moment at the column bottom and corresponding story drift (6-story frame) 
げモーメントが大きくなり，3 層骨組の最下層では図中 I から IIIま でに約 1.5 倍, 他層では約 2 倍となっている。層中間ピン柱脚骨組 では, 下層の塑性化した梁が曲げモーメントを負担できなくなると, 図 12 に示寸ように反曲点が下降し, 上層の柱作用曲げモーメントが 大きくなる。6 層及び 9 層骨組では, 3 層骨組より大きな頂部変形角 で全層梁降伏メカニズムが形成され, 上層の梁塑性化後には柱頭作 用曲げモーメントが 2 倍以上となる場合もある。修正 D 值法で求め た頂部変形角及び柱作用曲げモーメントは数值解析結果とよく対応 しており，柱が弾性保持するための曲げ耐力を明らかにした。

\section{4. 層中間ピン柱脚骨組の地震応答性状と柱作用曲げモーメント評} 価

本章では，地震動を受ける層中間ピン柱脚骨組の動的応答性状を 明らかにし, 地震応答解析結果と修正 D 值法による算定値から修正 $\mathrm{D}$ 值法の適用範囲を検証する。

\section{1 動的解析概要}

対象骨組の概要は, 静的解析と同様である。動的解析では, 地震 波を El Centro1940, Hachinohe1968, Taft1952, Tohoku1978, JMA Kobe1995, Sendai, Aoba 2011 ${ }^{13)}$, Kumamoto, Kumamoto $2016^{14)}$ の NS 波とする。また魚骨形骨組の 1 層あたりの質量を $615 \mathrm{kN}$ とする ${ }^{5)}$ 図 13 に最大速度が $50 \mathrm{~cm} / \mathrm{s}$ となるように基準化した各地震波の加速 度応答スペクトルを示す。

\section{2 動的解析結果}

図 14 及び図 15 に 6 層骨組における Taft $75 \mathrm{~cm} / \mathrm{s}$ 及び Sendai, Aoba $75 \mathrm{~cm} / \mathrm{s}$ での柱頭曲げモーメント比 $\left(M_{C t i m a x} / M_{p B i}\right)$ と層間変形角の関 係, 柱脚曲げモーメント比 $\left(M_{C b i+1 \max } / M_{p B i}\right)$ と層間変形角の関係を示 す。曲げモーメントは 1 層, 2 層及び 4 層梁に接合する柱頭及び柱 脚の曲げモーメントを示している。図 14 中に柱頭曲げモーメントの 最大值, 図 15 中に柱頭曲げモーメント最大時における柱脚曲げモー メント比をマで示す。

Taft $75 \mathrm{~cm} / \mathrm{s}$ では, 柱頭曲げモーメント比の 1 層, 2 層及び 4 層の 最大值は，層間変形角がそれぞれ-0.019 rad，-0.018 rad 及び-0.01 rad のとき， $-1.39,-1.80$ 及び-1.72 となり，そのときの柱脚曲げモーメ ント比は $0.61,0.20$ 及び 0.28 となる。柱頭曲げモーメントと柱脚曲 げモーメントの和は接合する 2 本の梁が全塑性曲げモーメントに達 したときの $M_{B i} / M_{p B i}$ の和である 2.00 となる。一方 Sendai, Aoba $75 \mathrm{~cm} / \mathrm{s}$ では，柱頭曲げモーメント比の 1 層， 2 層及び 4 層の最大值は，層 間変形角がそれぞれ $0.0141 \mathrm{rad} ， 0.0126 \mathrm{rad}$ 及び $0.0079 \mathrm{rad}$ のとき, $1.22,1.43$ 及び 1.30 となり, そのときの柱脚曲げモーメント比は-0.77, -0.47 及び-0.56である。柱頭曲げモーメントと柱脚曲げモーメント の和は 1 層, 2 層及び 4 層でそれぞれ $2.00,1.90$ 及び 1.86 となる。 なお， 1 層， 2 層及び 4 層柱頭曲げモーメント最大時までに， 1 層〜 4 層梁が塑性化した。梁が全塑性曲げモーメントに達しても柱頭曲 げモーメントが最大となるとは限らない。これは, 柱頭曲げモーメ ントの值は柱頭・柱脚の曲げモーメント分配比 (反曲点高さの違い) によるためである。

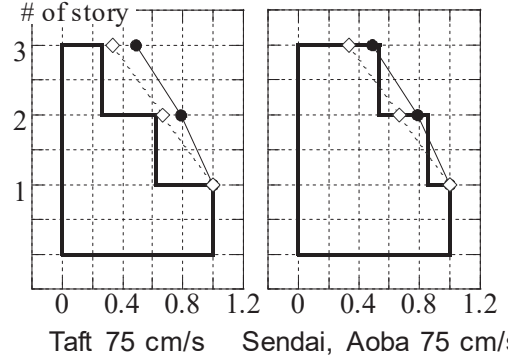

(a) 3-story frame

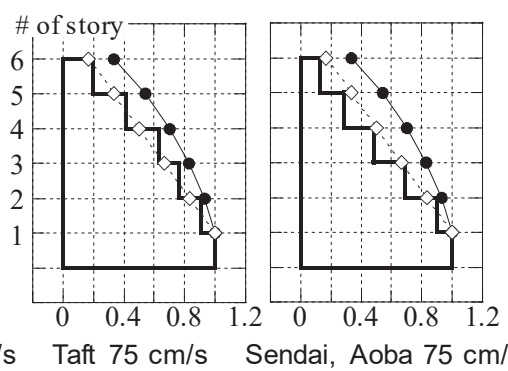

(b) 6-story frame

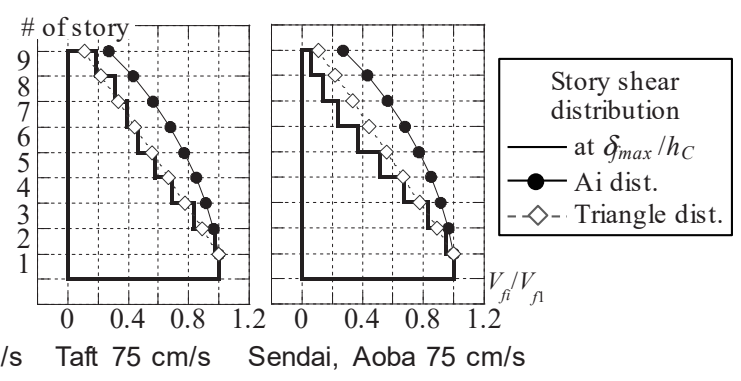

(c) 9-story frame

Fig.16 Story shear distribution at the maximum story drift $\left(d_{\max } / h_{c}\right)$

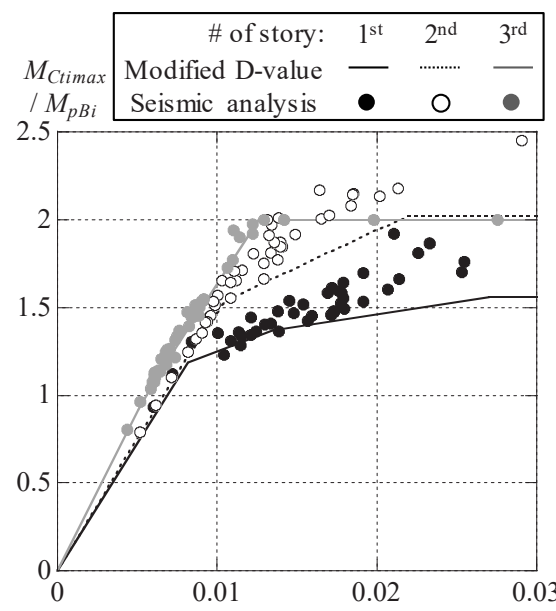

(a) 3-story frame

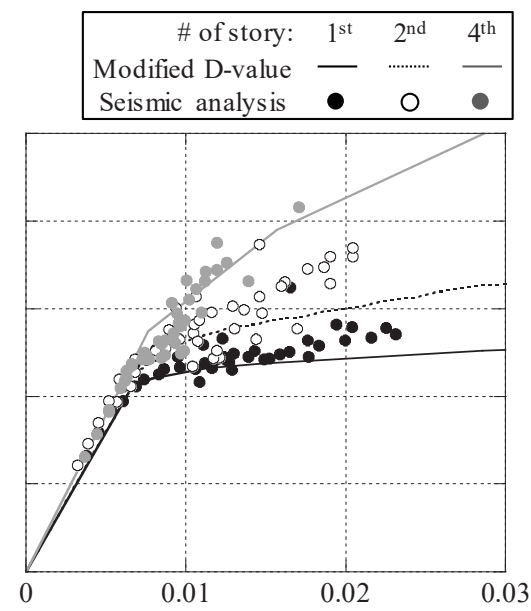

(b) 6-story frame

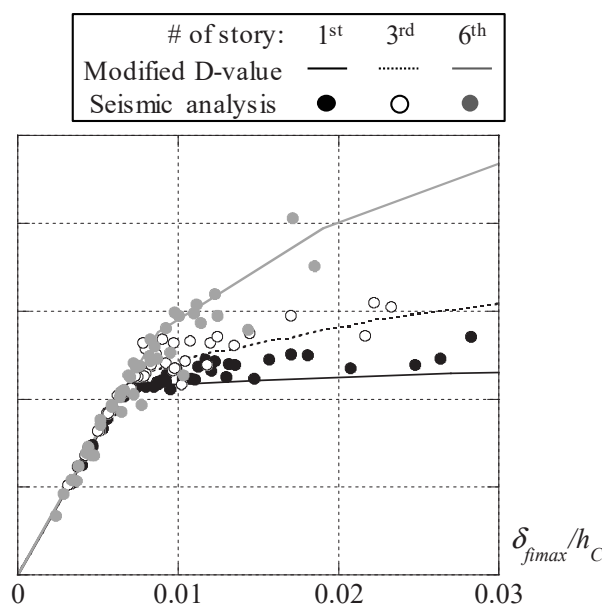

(c) 9-story frame

Fig.17 Relation between maximum moment of the column top and maximum story drift $\left(\delta_{\text {fmax }} / h_{c}\right)$ 
図 16 に Taft $75 \mathrm{~cm} / \mathrm{s}$ 及び Sendai, Aoba $75 \mathrm{~cm} / \mathrm{s}$ での全時刻中におけ る骨組の最大層間変形角時の作用 せん断力分布を示す。横軸は各層 の作用せん断力を 1 層作用せん断 力 $V_{f 1}$ で無次元化している。縦軸 は層数である。 $\mathrm{Ai}$ 分布と三角形分 布（つまり均一外力作用時）のせ ん断力分布を実線及び点線で重ね て示寸。3 層骨組の場合, Taft 75 $\mathrm{cm} / \mathrm{s}$ では三角形分布, Sendai, Aoba $75 \mathrm{~cm} / \mathrm{s}$ では Ai 分布による作用せ ん断力分布に近い。6 層骨組の場合, Taft $75 \mathrm{~cm} / \mathrm{s}$ では三角形分布と $\mathrm{Ai}$ 分布の間, Sendai, Aoba $75 \mathrm{~cm} / \mathrm{s}$ では三角形分布による作用せん断 力分布に近い。9 層骨組の場合, Taft $75 \mathrm{~cm} / \mathrm{s}$ では三角形分布, Sendai, Aoba $75 \mathrm{~cm} / \mathrm{s}$ では中間層で外力が大きくなるような作用せん断力分 布となっている。

図 17 では 3 層, 6 層及び 9 層骨組における最大柱頭曲げモーメン 卜比と最大層間変形角の関係に関寸る修正 $\mathrm{D}$ 值法と動的解析の結果 を比較している。横軸は $i$ 層最大層間変形角 $\left(\delta_{f i m a x} / h_{C}\right)$, 縦軸は $i$ 層最大柱頭曲げモーメント比 $\left(M_{\text {Ctimax }} / M_{p B i}\right)$ を示す。修正 D 值法は, 図 16 に示した $\mathrm{Ai}$ 分布に基づく作用せん断力時として算出した。動 的解析結果は, 7 種の地震波を $25 \mathrm{~cm} / \mathrm{s} \sim 50 \mathrm{~cm} / \mathrm{s}$ で $5 \mathrm{~cm} / \mathrm{s}$ 刻み, 及 び $75 \mathrm{~cm} / \mathrm{s}$ とし, 全時刻中における最大層間変形角 $\left(\delta_{\text {fimax }} / h_{C}\right)$ を横 軸に, 全時刻中における各層最大柱頭曲げモーメント比を縦軸にプ ロットしている。修正 D 值法と動的解析の結果は, 弾性範囲でよく 一致した。梁塑性化後, 動的解析が修正 D 值法を大きく上回る傾向 がある。修正 D 值法に対し, 図 17 で示した 3 層骨組の場合 Taft 75 $\mathrm{cm} / \mathrm{s}$ では $23 \%$, Sendai, Aoba $75 \mathrm{~cm} / \mathrm{s}$ では 3\%程度, 動的解析が上回 っている。同様に 6 層骨組の場合 Taft $75 \mathrm{~cm} / \mathrm{s}$ では 19\%, Sendai, Aoba $75 \mathrm{~cm} / \mathrm{s}$ では $8.5 \%, 9$ 層骨組の場合 Taft $75 \mathrm{~cm} / \mathrm{s}$ では 5\%, Sendai, Aoba $75 \mathrm{~cm} / \mathrm{s}$ では $13 \%$ 程度, 動的解析が上回っている。図 16 において, $\mathrm{Ai}$ 分布に近いせん断力が作用している場合は誤差が小さくなるも のの, 均一外力作用時もしくはそれよりもさらに中間層で外力が大 きくなるようなせん断力分布の場合, 柱頭作用曲げモーメントが大 きくなる傾向にある。

図 18 に動的解析における各層の最大柱頭曲げモーメント比と, そ の層の最大層間変形角に対応する修正 $\mathrm{D}$ 值法による最大柱頭曲げモ 一メント比との関係を示す。横軸が修正 D 值法, 縦軸が動的解析の 結果である。3 層骨組では 1 層, 2 層及び 3 層, 6 層骨組では 1 層, 2 層及び 4 層, 9 層骨組では 1 層, 3 層及び 6 層が最大となるときの 結果をプロットしている。動的解析が修正 D 值法を上回り, その差 が最大となるのは，3層骨組では Tohoku $75 \mathrm{~cm} / \mathrm{s}$ における 2 層柱頭 の $\delta_{\text {fimax }} / h_{C}=0.029 \mathrm{rad}$ 時の $M_{C \text { timax }} / M_{p B i}=2.45$ で誤差 $21 \%, 6$ 層骨組では Kumamoto, Kumamoto $75 \mathrm{~cm} / \mathrm{s}$ における 2 層柱頭の $\delta_{\text {fimax }} / h_{C}=0.015 \mathrm{rad}$ 時の $M_{C t i m a x} / M_{p B i}=1.86$ で誤差 31\%，9 層骨組では Kumamoto,

Kumamoto $75 \mathrm{~cm} / \mathrm{s}$ における 1 層柱頭の $\delta_{\text {fimax }} / h_{C}=0.028 \mathrm{rad}$ 時の $M_{C t i m a x} / M_{p B i}=1.36$ で誤差 $18 \%$ である。柱頭曲げモーメントが大きくな ると, 誤差が大きくなる傾向がみられ, 特に 2 層で顕著となる。こ れは, 動的解析と修正 D 值法の結果を同程度の層間変形角時におい

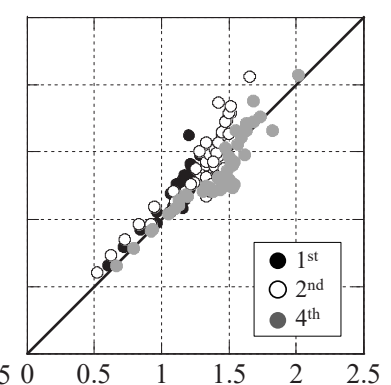

(b) 6-story frame

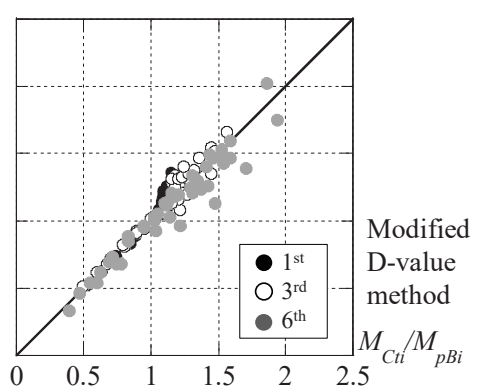

(c) 9-story frame arison of maximum moment at the column top て比較すると, 動的解析ではより上層まで梁が塑性化している傾向 がみられたことから，下層における反曲点は下降し，柱頭曲げモー メントが大きくなったためと考えられる。最大值を比較すると一部 で多少誤差があるものの, 修正 D 值法により動的解析の結果が概ね 捉えられている。

\section{5. 結}

本論文では，層中間ピン柱脚機構を有する鉄骨ラーメン骨組の弾 塑性範囲での力学特性の評価が可能となる修正 D 值法を提案した。 梁が塑性化するときの層間変形角と柱作用曲げモーメントの関係を 把握し, 各層の梁塑性ヒンジ形成時に柱が弾性保持するための柱曲 げ耐力を明らかにした。本論文で得た主な知見を以下に列挙寸る。

1) 層中間ピン柱脚骨組での層間変形角を導出するため, D 值法に柱 脚作用曲げモーメントの曲げ戻しや波及効果の考慮，塑性化後の最 下層柱頭の回転による変位算出の修正を加えた修正 D 值法を提案し, 静的増分解析でその妥当性を示した。

2) 静的増分解析及び修正 D 值法では，3 層骨組では頂部変形角 0.03 rad 時までに全層梁が塑性化し，6 層及び 9 層骨組では， 3 層骨 組より大きな層間変形角で全層梁降伏メカニズムが形成された。 3) 今回対象とした層中間ピン柱脚を適用した中低層の骨組モデル において, 頂部変形角 $0.03 \mathrm{rad}$ 時に柱を弾性に保つためには, 梁の 全塑性モーメントに対し 3 層では 2.0 倍程度, 6 層及び 9 層では 2.5 倍程度の柱曲げ耐力が必要となることを示した。

4) 動的解析では, 柱作用曲げモーメントは弾性範囲で修正 D 值法 とよく一致し，梁塑性化後，層間変形角 $0.03 \mathrm{rad}$ 時までに 3 層， 6 層及び 9 層骨組においてそれぞれ最大で $21 \%, 31 \%$ 及び $18 \%$, 動的 解析結果が修正 D 值法を上回るものの, 各骨組ともに修正 D 值法に より概ね傾向を捉えられている。

5) 修正 D 值法と動的解析結果における柱最大作用曲げモーメント の差が大きくなる理由として, せん断力分布が $\mathrm{Ai}$ 分布から三角形分 布に近づくこと，梁塑性化の進展が異なることを明らかにした。

今後さらに修正 D 值法の精度を高めるには, 算出時に用いるせん 断力分布に高次モードの影響を考慮する必要がある。

\section{謝辞}

本研究は, JST 産学共創プラットフォーム共同研究推進プログラム によるものである。また，本研究に取り組むにあたり，東京工業大学名 誉教授の和田章先生と構造計画プラス・ワン会長の金田勝徳先生にご指 
導いただいた。ここに深く感謝の意を示す。

\section{参考文献}

1) Building Guidance Division, Housing Bureau, the Ministry of Land, Infrastructure and Transport. Japan Conference of Building Officials. The Building Center of Japan.: Structural related technical standard commentary on buildings - 2007 edition, 2007 (in Japanese)

国土交通省住宅局建築指導課，日本建築主事会議，日本建築センター: 2007 年度版建築物の構造関係技術基準解説書, 2007

2) Yuko Shimada, Keiichiro Suita, Satoshi Yamada, Yuichi Matsuoka, Motohide Tada, Makoto Ohsaki, and Kazuhiko Kasai.: Experimental Procedure and Elastic Response Characteristics of Shaking Table Test - Complete Collapse Test of Full-Scale 4-Story Steel Building Part 3, Journal of Structural and Construction Engineering (Transactions of AIJ), Vol. 75, No. 653, pp.1351-1360, 2010.7 (in Japanese)

島田侑子, 吹田啓一郎, 山田哲, 松岡祐一, 多田元英, 大崎純, 笠井和 彦：振動台実験における倒壊挙動 一実大 4 層鉄骨造建物の完全崩壊実 験 その $3-$, 日本建築学会構造系論文集，第 75 巻，第 653 号, pp.1351-1360, 2010.7

3) Kiyoshi Muto.: Seismic Calculation Method, 1963 (in Japanese) 武藤清: 耐震計算法-而震設計シリーズ 1-, 1963

4) Katsunori Kaneda, Yoshihiro Kimura, Shinichi Hamasaki, and Akira Wada.: Proposal of New Column Support System for Multi-Story Moment Resisting Structures to Perform Beam Yielding Mechanism, Journal of Structural and Construction Engineering (Transactions of AIJ), Vol. 75, No. 654, pp.1537-1546, 2010.8 (in Japanese)

金田勝徳，木村祥裕，濱崎慎一，和田章：全層梁降伏型を目指した中低層鉄 骨ラーメン構造構築のための新しい柱脚機構の提案, 日本建築学会構造系 論文集, 第 75 巻, 第 654 号, pp.1537-1546, 2010.8

5) Katsunori Kaneda, Yoshihiro Kimura, Naoki Miyahara, and Akira Wada.: Ultimate Seismic Capacity of Multi-Story Steel Moment Resisting Frames Having New Column Support System, Journal of Structural and Construction Engineering (Transactions of AIJ), Vol. 76, No. 661, pp.649-658, 2011.3 (in Japanese)

金田勝徳，木村祥裕，宮原直樹，和田章：新しい柱脚機構を有する中低 層鉄骨ラーメン架構の終局耐震能力, 日本建築学会構造系論文集，第 76 巻, 第 661 号, pp.649-658, 2011.3

6) Koji Ogawa, Hisaya Kamura and Kazuo Inoue.: Modeling of The Moment Resistant Frame to Fishbone-Shaped Frame for The Response Analysis, Journal of Structural and Construction Engineering (Transactions of AIJ), No. 521, pp.119-126, 1999.7 (in Japanese)

小川厚治，加村久哉，井上一朗：鋼構造ラーメン骨組の魚骨形地震応答 解析モデル, 日本建築学会構造系論文集, 第 521 号, pp.119-126, 1999.7

7) Yoshihiro Kimura, Katsunori Kaneda, and Akira Wada.: Estimation of Ultimate Seismic Capacity and Column Demand of Multi-Story Steel Moment Resisting Frames with New Column Support System to Fishbone-Shaped Frame, Journal of Structural and Construction Engineering (Transactions of AIJ), Vol. 77, No. 675, pp.765-773, 2012.5 (in Japanese)

木村祥裕，金田勝徳，和田章：新しい柱脚支持機構を有する鉄骨ラーメン 骨組の終局耐震能力及び柱の要求性能評価に対する魚骨形骨組の適用, 日本建築学会構造系論文集, 第 77 巻, 第 675 号, pp.765-773, 2012.5

8) Yoshihiro Kimura, Katsunori Kaneda and Akira Wada.: Estimation of Shear and Axial Force for Steel Column Joints and Seismic Strength of Multi-Story Steel Moment Resisting Frames with New Column Support System, Journal of Structural and Construction Engineering (Transactions of AIJ), Vol. 78, No. 688, pp.1149-1158, 2013.6 (in Japanese)

木村祥裕，金田勝徳，和田章：新しい柱脚機構を有する鉄骨ラーメン骨 組の終局耐震能力と鉄骨柱支点部の作用力の算定法，日本建築学会構 造系論文集，第 78 巻，第 688 号, pp.1149-1158, 2013.6

9) Katsunori Kaneda, Yoshihiro Kimura, Kenta Mutsukura, Haruyoshi Kadoya, Toru Watanabe, and Kunihiro Takahashi.: Cyclic Loading Test for Partial Frames with New Column Support System for Multi-Story Steel Moment Resisting Structures to Perform Beam Yielding Mechanism, Journal of Structural and Construction Engineering (Transactions of AIJ), Vol. 76, No. 665, pp.1357-1366, 2011.7 (in Japanese)

金田勝徳，木村祥裕，六倉賢太，角屋治克，渡辺亨，高橋邦広：全層梁 降伏型中低層鉄骨ラーメン構造構築のための柱脚機構に関する部分架 構モデルによる基礎実験，日本建築学会構造系論文集，第 76 巻，第 665 号, pp.1357-1366, 2011.7

10) Miyu Irisawa, Yoshihiro Kimura, and Sachi Furukawa.: Estimation of Column Strength in Multi-Story Steel Moment Resisting Frames with New Column Support System, Summaries of Technical Papers of Annual Meeting, Architectural Institute of Japan, Structures-III, pp.703-706, 2016.7 (in Japanese)

入沢美優, 木村祥裕, 古川幸: 二方向地震動を受ける層中間ピン柱脚鋼 構造ラーメン骨組における柱の要求性能, 日本建築学会大会学術講演 梗概集，構造 III, pp.703-706, 2016.7

11) Yoshihiro Kimura, Yohei Matsuo and Yasunori Nakazawa.: Story Drift Concentration and Hysteresis Energy for Two Story Braced Frame with Buckling Braces Subjected to Strong Motion, Journal of Structural and Construction Engineering (Transactions of AIJ), Vol. 77, No. 672, pp.293-301, 2012.2 (in Japanese)

木村祥裕, 松尾陽平, 中澤泰典: 強震を受ける座屈劣化型二層ブレース 構造物の履歴吸収エネルギーと層間変形集中に対する弾性柱材曲げ剛 性の影響 日本建築学会構造系論文集, 第 77 巻, 第 672 号, pp.293-301, 2012.2

12) Building Research Institute.: Cold-formed square steel pipe design and construction manual - 2008 edition, 2008.12 (in Japanese)

独立法人建築研究所: 2008 年版冷間成形角形鋼管設計・施工マニュアル, 2008.12

13) Strong-motion Records on Buildings and Ground of the 2011 Tohoku Region Pacific Offshore Earthquake, Architectural Institute of Japan, Tohoku, 2013.6. 東北地方で観測された 2011 年東北地方太平洋沖地震の建物・地盤系強 震データ集, 日本建築学会東北支部, 2013.6

14) Strong-motion Seismograph network (K-NET, Kik-net), National Research Institute for Earth Science and Disaster Resilience. (accessed 2019.2.20) 防災科学技術研究所強震観測網(K-NET, Kik-net), 防災科学技術研究所, http://www.kyoshin.bosai.go.jp/kyoshin/, 2019/2/20 ダウンロード

付録 $1: y_{1 i}$ の算出

文献 3)より， $y_{1 i}$ の算出における 3 モーメント方程式は次の形をとる。

$$
\begin{aligned}
& i \leq j-1 \quad M_{i-1}-(2+6 k) M_{i}+M_{i+1}=3 k V_{f} h_{C} \quad \text { (付 1.1 } \\
& i=j \quad M_{j-1}\left(1+\frac{1}{{ }_{1} \alpha_{j}}+6 k\right) M_{j}+\frac{1}{{ }_{1} \alpha_{j}} M_{j+1}=-\left(\frac{1}{{ }_{1} \alpha_{j}}-1+3 k\right) V_{f} h_{C}
\end{aligned}
$$

(付 1.1)（文献 3) (4.43)

$i \geq j+1 M_{i-1}-\left(2+6_{1} \alpha_{j} k\right) M_{i}+M_{i+1}=-3_{1} \alpha_{j} k V_{f} h_{C}$ (付 1.1b)（文献 3) (4.43b) 3 モ一メント方程式の解は式(5)中の $r$ 及び $r$ 'を用いて以下のようになる。

$$
\begin{array}{ll}
i \leq j-1 M_{i}=\left(0.5+C r^{j-i}\right) V_{f} h_{C} & \text { (付 1.2a)（文献 3) (4.44) } \\
i \geq j+1 M_{i}=\left(0.5+C r^{1 j-i}\right) V_{f} h_{C} & \text { (付 1.2b)（文献 3) (4.44) }
\end{array}
$$

ここで，Cは積分定数で，C= $y_{1 i}$ となる。

文献 3)では式(付 2.2a), (付 2.2b)を式(付 2.1)に代入した解として, $C$ を以下の ように示した。

$$
C=\frac{1-{ }_{1} \alpha_{j}}{{ }_{1} \alpha_{j}(1-r)-\left(r^{\prime}-1\right)+6 k}
$$

しかし，実際に式(付 2.2a)，(付 2.2b)を式(付 2.1)に代入するとCは以下のように 定められるため, 本論文ではこれを用いた。

$$
C=\frac{1-{ }_{1} \alpha_{j}}{{ }_{1} \alpha_{j}(1-r+6 k)-\left(r^{\prime}-1\right)}
$$

付録 2: $a_{i 1}, a_{i 2}$ の算出

一般層の層剛性 $K_{f i}$ は, 文献 3)の D 值法においいて反曲点高さ比を 0.5 に固定 
し，上下の梁の平均剛比 $\bar{k}$ にる簡略的な算出方法が例示されているが，文 献 10)では層剛性をより高い精度で算出するため, 柱上下の梁の材端回転角を 考慮したたわみ角法により求める方法を採用した。層の拘束度を表す係数 $a_{i}$ については, 上下梁と柱に関するたわみ角法による 3 つの構成方程式((付 2.2) 式（付 2.3)式及び(付 2.4)式）から柱脚部節点回りの釣合式（(付 2.6)式）と柱 頭部節点回りの釣合式（(付 2.11)式）を算出する。(付 2.6) (付 2.7)式と層方程 式（(付 2.8)式）から, 下層に対する係数 $a_{i 1}$ と柱頭部節点回りの釣合式から算 出した上層に対する係数 $a_{i 2}$ の 2 式を算出できる。そこに, 2.2 .1 項で求めた反 曲点高さ比 $y_{i}$ を代入し, 層の拘束度を算出する。

以下に, $a_{i}$ 值の導出過程を示す。

$i$ 層柱脚及び柱頭曲げモーメントについて,

$$
\frac{M_{C i i}}{1-y_{i}}=\frac{M_{C b i}}{y_{i}} \quad \therefore M_{C i}=\frac{1-y_{i}}{y_{i}} M_{C b i}
$$

たわみ角法の公式より，

$$
\begin{aligned}
& \left\{\begin{array}{l}
M_{C b i} \\
M_{C i i}
\end{array}\right\}=2 E k_{C i}\left[\begin{array}{ll}
2 & 1 \\
1 & 2
\end{array}\right]\left\{\begin{array}{l}
\theta_{C b i}-R \\
\theta_{C i t}-R
\end{array}\right\}=2 E k_{C i}\left\{\begin{array}{l}
2 \theta_{C b i}+\theta_{C i i}-3 R \\
\theta_{C b i}+2 \theta_{C i i}-3 R
\end{array}\right\} \\
& \left\{\begin{array}{l}
M_{B i-1} \\
M_{B i-1}
\end{array}\right\}=2 E k_{B i-1}\left[\begin{array}{ll}
2 & 1 \\
1 & 2
\end{array}\right]\left\{\begin{array}{l}
\theta_{C b i} \\
\theta_{C b i}
\end{array}\right\}=2 E k_{C i}\left\{\begin{array}{l}
3 \theta_{C b i} \\
3 \theta_{C b i}
\end{array}\right\} \\
& \left\{\begin{array}{l}
M_{B i} \\
M_{B i}
\end{array}\right\}=2 E k_{B i}\left[\begin{array}{ll}
2 & 1 \\
1 & 2
\end{array}\right]\left\{\begin{array}{l}
\theta_{C i i} \\
\theta_{C t i}
\end{array}\right\}=2 E k_{C i}\left\{\begin{array}{l}
3 \theta_{C i i} \\
3 \theta_{C i i}
\end{array}\right\}
\end{aligned}
$$

(付 2.3)式を(付 2.4)式に代入して, たわ角 $\theta_{C b i}$ を求める。

$$
\theta_{C b i}=\frac{1-3 y_{i}}{3 y_{i}-2} \theta_{C t i}+\frac{3\left(2 y_{i}-1\right)}{3 y_{i}-2} R
$$
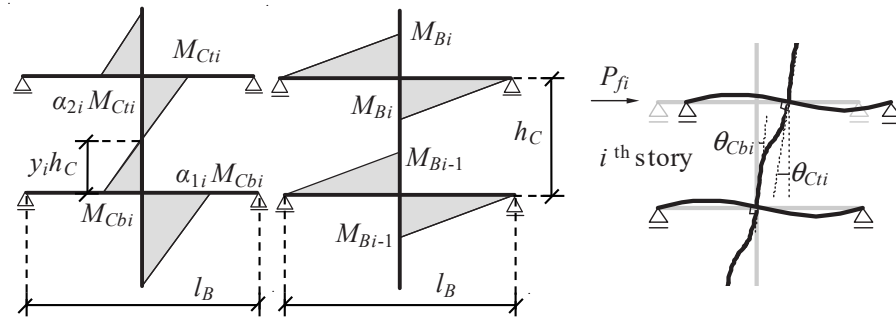

$i$ 層柱脚部節点回りのつり合いについは, 次式で表される。

$$
\begin{aligned}
& \text { A.Fig.1 Moment distribution } \\
& \text { for story unit model } \\
& \therefore \theta_{C t i}=-\frac{3\left(2 y_{i}-1\right) k_{i}^{\prime}+\left(1+\alpha_{1 i}{ }^{\prime}\right) y_{i}}{\left(1-3 y_{i}\right) k_{i}^{\prime}-\left(1+\alpha_{1 i}^{\prime}\right) y_{i}} R \\
& M_{C i i}+M_{C i t}+V_{f i} h_{C}=0 \\
& 12 E K k_{C i} R \cdot \frac{1}{2} \frac{-k_{i}^{\prime}}{\left(1-3 y_{i}\right) k_{i}^{\prime}-\left(1+\alpha_{1 i}{ }^{\prime}\right) y_{i}}=V_{f i} h_{C} \\
& \therefore a_{i 1}=\frac{1}{2} \cdot \frac{-k_{i}^{\prime}}{\left(1-3 y_{i}\right) k_{i}^{\prime}-\left(1+\alpha_{1 i}{ }^{\prime}\right) y_{i}}, \quad k_{i}^{\prime}=2 k_{B i-1} / k_{C i}
\end{aligned}
$$

$i$ 層柱頭部節点の釣り合いについては, 次式で表される。

$$
2 M_{B i}+M_{C t i}+\alpha_{2 i}{ }^{\prime} M_{C t i}=0
$$

\begin{tabular}{|c|c|}
\hline$n$ & 層数 \\
\hline$m$ & 塑性化層の柱頭位置の層 \\
\hline$i$ & 対象層 \\
\hline$y_{i}$ & $i$ 層の反曲点高さ \\
\hline$y_{0 i}$ & $i$ 層の標準反曲点高さ \\
\hline$y_{1 i}$ & 上下梁の剛比変化による $i$ 層反曲点高さの修正值 \\
\hline$y_{2 i}$ & 上層の層高変化によるi層反曲点高さの修正值 \\
\hline$y_{3 i}$ & 下層の層高変化による $i$ 層反曲点高さの修正値 \\
\hline$y_{4 i}$ & 柱脚形式の変化による $i$ 層反曲点高さの修正值 \\
\hline$k_{B i}$ & $i$ 層梁の曲げ岡性 \\
\hline$k_{C i}$ & $i$ 層柱の曲げ岡性 \\
\hline$k_{i}$ & $i$ 層の柱梁曲げ岡比 \\
\hline$h_{C i}$ & $i$ 層の層高さ \\
\hline$l_{B i}$ & $i$ 層の梁のスパン長 \\
\hline$I_{B i}$ & $i$ 層の梁断面二次モーメント \\
\hline$I_{C i}$ & $i$ 層の柱断面二次モーメント \\
\hline$E$ & ヤング係数 \\
\hline$P_{f i}$ & 骨組 $i$ 層柱頭に作用する水平力 \\
\hline$V_{f i}$ & 骨組i層に作用するせん断力 \\
\hline$M_{B i}$ & $i$ 層の梁曲げモーメント \\
\hline$M_{C t i}$ & i層の柱頭曲げモーメント \\
\hline$M_{C b i}$ & 層の柱脚曲げモーメント \\
\hline$k_{i}$ & 基準骨組 $i$ 層の柱梁曲げ剛比 \\
\hline$h_{C}$ & 基準骨組の層高さ \\
\hline$V_{f}$ & 基準骨組に作用する均一せん断力 \\
\hline$r$ & 基準骨組の波及率 \\
\hline$r^{\prime}$ & 梁の曲げ岡性が変化した層への波及率 \\
\hline${ }_{1} \alpha_{j}$ & $j$ 層の梁の曲げ岡性の変化の比率 \\
\hline${ }_{2} \alpha_{j}$ & $j$ 層の層高の変化の比率 \\
\hline${ }_{y 1 j} M_{C i}$ & $\begin{array}{l}\text { 下もしくは上の柱梁曲げ剛比の変化による } i \text { 層の曲げモーメントの変 } \\
\text { 動值 }\end{array}$ \\
\hline${ }_{y 2 j} M_{C j}$ & $j$-1層柱頭曲げモーメントとの j層の不釣り合い曲げモーメント \\
\hline $\begin{array}{l}{ }_{33 j} M_{C j} \\
{ }_{y 01} M_{C b}\end{array}$ & $j+1$ 層柱脚曲げモーメントとの $j$ 層の不釣り合い曲げモーメント \\
\hline $\begin{array}{l}{ }^{y 01} M_{C b} \\
y_{1 j} M_{C b}\end{array}$ & $\begin{array}{l}y_{01} \text { より算出した最下層柱脚作用曲げモーメント } \\
y_{11} \text { より算出した最下層柱脚作用曲げモーメント }\end{array}$ \\
\hline${ }_{y 41} M_{C}$ & $\begin{array}{l}\text { 最下層での反曲点高さが層中間のピン支承部位置に一致するように作 } \\
\text { 用させる修正曲げモーメント }\end{array}$ \\
\hline$H_{m}$ & $\begin{array}{l}\text { 最下層の層中間ピン柱脚部から梁が弾性である } m \text { 層を柱頭とする層 } \\
\text { (塑性化層) の層高さ }\end{array}$ \\
\hline$H_{i}$ & 柱脚のピン接合部からi層柱頭までの高さ \\
\hline$\delta_{f i}$ & $i$ 層の層間変位 \\
\hline$K_{f i}$ & $i$ 層の層剛性 \\
\hline$a_{i}$ & $i$ 層柱の上下層梁による回転拘束度を表す係数 \\
\hline$a_{1 i}$ & $i$ 層柱の下層梁による回転拘束度を表す係数 \\
\hline$a_{2 i}$ & $i$ 層柱の上層梁による回転拘束度を表す係数 \\
\hline$D_{i}$ & $i$ 層柱頭の水平変位 \\
\hline$D_{B i}$ & 塑性化層の柱の曲げによるi層柱頭の水平変位 \\
\hline$D_{B i, j}$ & $j$ 層に作用する水平力 $P_{f j}$ に対する $i$ 層柱頭の水平変位 \\
\hline$P_{f m}^{\prime}$ & 塑性化層の柱柱頭に作用する水平力 \\
\hline$D_{R i}$ & 柱頭の回転による $i$ 層柱頭の水平変位 \\
\hline$\theta_{m}$ & $m$ 層梁の端部回転角 \\
\hline$D_{R i, m}$ & $\begin{array}{l}\text { 塑性化層の柱の上端に取り付く梁の端部回転角 } \theta_{m} \text { により生じる } i \text { 層柱 } \\
\text { 頭の水平変位 }\end{array}$ \\
\hline$\Delta M_{B m}$ & $m$ 層梁塑性化時における増分曲げモーメント \\
\hline$M_{p B m}$ & $m$ 層梁全塑性モーメント \\
\hline $\begin{array}{l}M_{B m(m-} \\
1)\end{array}$ & $m$-1層梁塑性化時の $m$ 層梁の曲げモーメント \\
\hline$M_{C i(m)}$ & $m$ 層梁塑性化時のi層柱の曲げモーメント \\
\hline$V_{f i(m)}$ & $m$ 層梁塑性化時の $i$ 層作用せん断力 \\
\hline$\delta_{f(m)}$ & $m$ 層梁塑性化時のi層の層間変位 \\
\hline$K_{R}$ & $m$ 層梁の端部回転角に対応する回転剛性 \\
\hline$\Delta$ & 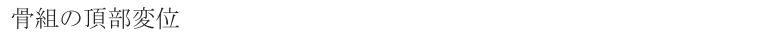 \\
\hline
\end{tabular}

ここで, $\frac{y_{i}-1}{3 y_{i}-2}=y^{\prime}$ とおくと，

$$
12 E K\left\{k_{B i}+\frac{1}{2} y^{\prime}\left(1+\alpha_{2 i}{ }^{\prime}\right) k_{C i}\right\} \theta_{C t i}=12 E K k_{C i} \frac{1}{2} y^{\prime} R\left(1+\alpha_{2 i}{ }^{\prime}\right)
$$

となり, 層方程式より柱脚部の場合と同様に $a_{2 i}$ が定められる。

$$
\begin{gathered}
12 E K k_{a} R \cdot \frac{1}{2} \cdot \frac{-k_{i}}{\left(3 y_{i}-2\right) k_{i}+\left(1+\alpha_{2 i}{ }^{\prime}\right)\left(y_{i}-1\right)}=V_{f i} h_{C} \\
\therefore a_{i 2}=\frac{1}{2} \cdot \frac{-k_{i}}{\left(3 y_{i}-2\right) k_{i}+\left(1+\alpha_{2 i}{ }^{\prime}\right)\left(y_{i}-1\right)}
\end{gathered}
$$

付録 3 : 記号定義

付表 1 に本論文で用いた記号定義の一覧を示す。

\section{A.Table.1 Symbol list}




\title{
MODIFIED D-VALUE METHOD TO PREDICT SEISMIC STRENGTH OF MULTI-STORY STEEL MOMENT RESISTING FRAMES WITH MID-STORY PIN COLUMN BASE SYSTEM
}

\author{
Yoshihiro KIMURA ${ }^{* 1}$, Motoko ANDO ${ }^{* 2}$ and Sachi FURUKAWA ${ }^{* 3}$ \\ ${ }^{* 1}$ Prof., Graduate School of Eng., Tohoku University, Dr.Eng. \\ *2 Akita Prefectural Office, M.Eng. \\ *3 Assist. Prof., Graduate School of Eng., Tohoku University, Dr.Eng.
}

With an embedded type column base, or a fixed column base, column bases of the first story columns for frames designed following current design codes may yield simultaneously when the second story beams yield, because it cannot be avoided that the bending moment become substantially large at the base. Kimura et.al [4] has proposed the concept to realize beam yielding mechanism of a steel moment-resisting frame by applying a pin-support column base system to midpoints of the first story columns. With a proposed column support system, or mid-story pin column base system, it can be reliably designed that the first story columns remain in elastic until the maximum story drift of a frame exceeds $0.03 \mathrm{rad}$. While seismic performance of the frame is significantly improved with this new column base system, yielding of columns must be prevented or collapse mechanism may be formed.

In practice, structural design requires multiple trials to optimize selection of structural components whether their combinations meet seismic demands on a frame. The D-value method [3] is a design method based on fundamental structural mechanics to predict story drift distribution of a moment-resisting frame under designated lateral force distribution. The $\mathrm{D}$-value method has advantage to predict structural performance directly with respect to structural properties.

This paper evaluates seismic performance, especially flexural demand on columns for a moment-resisting steel frame adopting a mid-story pin column base to maintain them elastic until a frame reaches the ultimate limit state. Because the original D-value method is only applicable to a frame with linear structural behavior and with a conventional column base, it is extended to predict elasto-plastic behavior of frames. In the proposed modified D-value method, replacement of column base to a mid-story pin column base is simply considered as shift of the location of an inflection point in the first story column. In addition, rotational restriction of the column by plastic beams is neglected to calculate moment and displacement distribution of the plastic stories in the incremental steps, assuming a beam has the perfect-plastic behavior.

The major findings of this paper can be summarized as follows:

1) The proposed modified D-value method successfully predicts mechanical behavior calculated by static analysis.

2) Series of static analysis shows that beam yielding mechanism is formed by reaching a story drift ratio of larger than $0.03 \mathrm{rad}$, and that required flexural demand on the column reaches twice as large as the full-plastic moment of the beams for a 3-story frame and exceeds for 6- and 9-story frames.

3) Seismic analysis shows that column moments calculated by the modified D-value method sufficiently agree with those calculated by simulation while response of frames remains in elastic range. Once the response of frames goes into the plastic range, calculational errors are increased up to $21 \%, 31 \%$ and $18 \%$ for $2^{-}, 6^{-}$- and 9 -story frames. Seismic analysis tends to yield larger column moment, but still the global trend such as in the relation between the maximum moment of the column and the maximum story drift is sufficiently reproduced by the modified $\mathrm{D}$-value method.

4) The larger maximum moment of the column calculated by simulation is thought to be caused by two reasons: one is that story shear distribution at recording the maximum moment of the column becomes closer to triangle story shear distribution rather than Ai distribution, which is adopted in calculation by the modified D-value method, and the other is that sequence of beam plasticity of the frames are substantially changed from those assumed in the D-value method. 